Article

\title{
Role of Efflux Pump-Mediated Antibiotic Resistance in Quorum Sensing-Regulated Biofilm Formation by Salmonella Typhimurium
}

\author{
Jirapat Dawan ${ }^{1}$, Yinyue $\mathrm{Li}^{2}$, Feng $\mathrm{Lu}^{2}$, Xinlong $\mathrm{He}^{2}$ and Juhee Ahn ${ }^{1, * \mathbb{D}}$ \\ 1 Department of Biomedical Science, Institute of Bioscience and Biotechnology, Kangwon National University, \\ Chuncheon 24341, Gangwon, Korea; jirapat@kangwon.ac.kr \\ 2 Institute of Translational Medicine, Medical College, Yangzhou University, Yangzhou 225001, China; \\ lyy1242602847@163.com (Y.L.); lufeng@yzu.edu.cn (F.L.); hexl@yzu.edu.cn (X.H.) \\ * Correspondence: juheeahn@kangwon.ac.kr; Tel.: +82-33-250-6564
}

Citation: Dawan, J.; Li, Y.; Lu, F.; He, X.; Ahn, J. Role of Efflux PumpMediated Antibiotic Resistance in Quorum Sensing-Regulated Biofilm Formation by Salmonella Typhimurium. Pathogens 2022, 11 147. https://doi.org/10.3390/ pathogens 11020147

Academic Editor: Lawrence S. Young

Received: 29 December 2021

Accepted: 24 January 2022

Published: 24 January 2022

Publisher's Note: MDPI stays neutral with regard to jurisdictional claims in published maps and institutional affiliations.

Copyright: (C) 2022 by the authors. Licensee MDPI, Basel, Switzerland. This article is an open access article distributed under the terms and conditions of the Creative Commons Attribution (CC BY) license (https:// creativecommons.org/licenses/by/ $4.0 /)$

\begin{abstract}
This study was designed to assess the influence of efflux pump activity on the biofilm formation in Salmonella Typhimurium. Salmonella enterica subsp. enterica serovar Typhimurium ATCC 19585 (ST ${ }^{\mathrm{WT}}$ ) and clinically isolated S. Typhimurium CCARM $8009\left(\mathrm{ST}^{\mathrm{CI}}\right)$ were treated with ceftriaxone (CEF), chloramphenicol (CHL), ciprofloxacin (CIP), erythromycin (ERY), norfloxacin (NOR), and tetracycline (TET) in autoinducer-containing media in the absence and presence of phenylalanine-arginine $\beta$-naphthylamide $(\mathrm{PA} \beta \mathrm{N})$ to compare efflux pump activity with biofilmforming ability. The susceptibilities of $\mathrm{ST}^{\mathrm{WT}}$ and $\mathrm{ST}^{\mathrm{CI}}$ were increased in the presence of PA $\beta \mathrm{N}$. $\mathrm{ERY}+\mathrm{PA} \beta \mathrm{N}$ showed the highest decrease in the minimum inhibitory concentration (MIC) of ERY from 256 to $2 \mu \mathrm{g} / \mathrm{mL}$ against ST ${ }^{\mathrm{WT}}$ and $\mathrm{ST}^{\mathrm{CI}}$. The antimicrobial activity of NOR against planktonic cells was significantly increased in the presence of PA $\beta N$, showing the lowest numbers of ST WT $\left(3.2 \log \mathrm{CFU} / \mathrm{cm}^{2}\right)$, and the TET+PA $\beta \mathrm{N}$ effectively inhibited the growth of $\mathrm{ST}^{\mathrm{CI}}\left(5.2 \mathrm{log} \mathrm{CFU} / \mathrm{cm}^{2}\right)$. The lowest biofilm-forming abilities were observed at $\mathrm{NOR}+\mathrm{PA} \beta \mathrm{N}$ against $\mathrm{ST}^{\mathrm{WT}}$ (biofilm-forming index, $\mathrm{BFI}<0.41)$ and $\mathrm{CEF}+\mathrm{PA} \beta \mathrm{N}$ against $\mathrm{ST}^{\mathrm{CI}}(\mathrm{BFI}=0.32)$. The bacteria swimming motility and relative fitness varied depending on the antibiotic and $\mathrm{PA} \beta \mathrm{N}$ treatments. The motility diameters of $\mathrm{ST}^{\mathrm{WT}}$ were significantly decreased by $\mathrm{NOR}+\mathrm{PA} \beta \mathrm{N}(6 \mathrm{~mm})$ and $\mathrm{TET}+\mathrm{PA} \beta \mathrm{N}(15 \mathrm{~mm})$, while the lowest motility of $\mathrm{ST}^{\mathrm{CI}}$ was observed at $\mathrm{CIP}+\mathrm{PA} \beta \mathrm{N}(8 \mathrm{~mm})$. The significant decrease in the relative fitness levels of $\mathrm{ST}^{\mathrm{WT}}$ and $\mathrm{ST}^{\mathrm{CI}}$ was observed at $\mathrm{CIP}+\mathrm{PA} \beta \mathrm{N}$ and NOR+PA $\beta \mathrm{N}$. The PA $\beta \mathrm{N}$ as an efflux pump inhibitor (EPI) can improve the antimicrobial and anti-biofilm efficacy of antibiotics against $S$. Typhimurium. This study provides useful information for understanding the role of efflux pump activity in quorum sensing-regulated biofilm formation and also emphasizes the necessity of the discovery of novel EPIs for controlling biofilm formation by antibiotic-resistant pathogens.
\end{abstract}

Keywords: Salmonella; biofilm; antibiotic susceptibility; efflux pump inhibitor

\section{Introduction}

Over the last few decades, antibiotics have been indiscriminately overused and misused in the treatment of infectious diseases. However, the extensive use of antibiotics has accelerated the emergence and spread of multidrug-resistant pathogens, leading to frequent treatment failure due to the limited chemotherapeutic options [1]. Salmonella Typhimurium is highly resistant to various antibiotic classes such as $\beta$-lactams and fluoroquinolones, resulting in treatment failure and increased morbidity and mortality [2]. The acquired multidrug resistance in bacteria can be caused by many mechanisms, including reduced membrane permeability, enzymatic modification, target site alteration, protective shield formation, and efflux pump activity [3]. Among these mechanisms, the efflux pumps are known primarily to confer multidrug resistance in bacteria [4]. The multidrug-resistant bacteria can expel different classes of antibiotics through well-developed efflux pump 
systems such as adenosine triphosphate (ATP)-binding cassette (ABC) superfamily, major facilitator superfamily (MFS), small multidrug resistance (SMR) family, multidrug and toxic compound extrusion (MATE) family, and resistance nodulation division (RND) superfamily $[4,5]$. The RND efflux pumps as polyspecific transporters are directly responsible for multidrug resistance in Salmonella strains [6].

The antibiotic substrates of single-component efflux pumps pass through the inner membrane into the periplasmic space in Gram-negative bacteria, and the transported antibiotic substrates traverse the outer cell membrane through multiple-component efflux pumps consisting of an inner membrane transporter, periplasmic membrane fusion, and $\beta$-barrel channel proteins [7]. In addition, the multidrug efflux pump system has drawn increasing attention as a potential therapeutic target to control biofilm formation [3]. A bacterial cell-to-cell communication system, regulated by a cell density-dependent manner, known as quorum sensing (QS), coordinates the formation of biofilm cells that are highly resistant to antibiotics [3]. Chromobacterium violaceum is commonly known as an acyl-homoserine lactone (AHL) producer, which regulates the production of proteases or pigment compounds such as violacein [8]. The AHLs secreted from C. violaceum can transfer across bacterial cells and induce the QS-controlled virulence and pathogenicity [8]. In addition, the multidrug efflux pumps are involved in the secretion of QS-signaling molecules such as autoinducer 1 (AI-1) and autoinducer 2 (AI-2), which are involved in biofilm formation [5]. Furthermore, the efflux pump-related genes are more expressed in biofilm cells than planktonic cells $[9,10]$. The overexpression of efflux-related genes corresponds to the overexpression of QS-related genes [11]. Efflux pump inhibitors (EPIs) can block the transport of QS-signaling molecules across membrane channels, resulting in the disruption of biofilm formation [3,12]. Hence, the inhibition of efflux pump expression plays an important role in controlling biofilm formation regulated by QS [13]. However, there is still a lack of knowledge regarding the effect of multidrug efflux pumps on the biofilm formation. Therefore, the aims of this study were to evaluate the antibiotic susceptibility and biofilm-forming ability of Salmonella Typhimurium ATCC 19585 $\left(\mathrm{ST}^{\mathrm{WT}}\right)$ and clinically isolated antibiotic-resistant $S$. Typhimurium CCARM $8009\left(\mathrm{ST}{ }^{\mathrm{CI}}\right)$ in the presence of phenylalanine-arginine $\beta$-naphthylamide $(\mathrm{PA} \beta \mathrm{N})$ and also investigate the relationship between efflux pump activity and biofilm formation of $\mathrm{ST}^{\mathrm{WT}}$ and $\mathrm{ST}^{\mathrm{CI}}$ in C. violaceum-cultured cell-free supernatant (CFS).

\section{Results}

\subsection{Antibiotic Susceptibilities of Salmonella Typhimurium Exposed to Efflux Pump Inhibitor}

$\mathrm{ST}^{\mathrm{WT}}$ and $\mathrm{ST}^{\mathrm{CI}}$ used in this study have different antibiotic resistance profiles, as shown in Table 1. The antibiotic susceptibilities of $\mathrm{ST}^{\mathrm{WT}}$ and $\mathrm{ST}^{\mathrm{CI}}$ were evaluated in the absence and presence of EPI, phenylalanine-arginine $\beta$-naphthylamide (PA $\beta N 120 \mu \mathrm{g} / \mathrm{mL}$ ) (Table 1). The antibiotic susceptibility patterns of $\mathrm{ST}^{\mathrm{WT}}$ and $\mathrm{ST}^{\mathrm{CI}}$ exposed to $\mathrm{PA} \beta \mathrm{N}$ varied in the classes of antibiotics. The antibiotic activities of ceftriaxone (CEF), chloramphenicol (CHL), ciprofloxacin (CIP), erythromycin (ERY), norfloxacin (NOR), and tetracycline (TET) against $\mathrm{ST}^{\mathrm{WT}}$ and $\mathrm{ST}^{\mathrm{CI}}$ were increased in the presence of $\mathrm{PA} \beta \mathrm{N}$ (Figure 1). The minimum inhibitory concentration (MIC) of CEF against ST ${ }^{\mathrm{WT}}$ was decreased from 0.25 to $0.125 \mu \mathrm{g} / \mathrm{mL}$ when treated with $\mathrm{PA} \beta \mathrm{N}$. Although the growth of $\mathrm{ST}^{\mathrm{CI}}$ was slightly decreased at $\mathrm{CEF}+\mathrm{PA} \beta \mathrm{N}$, the addition of PA $\beta \mathrm{N}$ did not affect the MIC of CEF against ST ${ }^{\mathrm{CI}}$. The MICs of CHL against $\mathrm{ST}^{\mathrm{WT}}$ and $\mathrm{ST}^{\mathrm{CI}}$ were decreased from 8 to $2 \mu \mathrm{g} / \mathrm{mL}$ in the presence of PA $\beta \mathrm{N}$. The susceptibilities of ST ${ }^{\mathrm{WT}}$ and $\mathrm{ST} \mathrm{CI}^{\mathrm{CI}}$ to CIP, ERY, NOR, and TET were increased in the presence of PA $\beta N$. The ERY $+\mathrm{PA} \beta N$ showed the highest decrease in the MIC from 256 to $2 \mu \mathrm{g} / \mathrm{mL}$ toward ST ${ }^{\mathrm{WT}}$ and $\mathrm{ST}^{\mathrm{CI}}$. The highest MIC was observed for ST ${ }^{\mathrm{CI}}$ treated with TET $(512 \mu \mathrm{g} / \mathrm{mL})$ and was significantly decreased in the presence of PA $\beta N$ (Figure 1). 
Table 1. Minimum inhibitory concentrations (MICs; $\mu \mathrm{g} / \mathrm{mL}$ ) of Salmonella Typhimurium ATCC 19585 $\left(\mathrm{ST}^{\mathrm{WT}}\right)$ and clinically isolated antibiotic-resistant $S$. Typhimurium CCARM $8009\left(\mathrm{ST}^{\mathrm{CI}}\right)$ in the absence and presence of phenylalanine-arginine-b-naphthylamide $(\mathrm{PA} \beta \mathrm{N})$.

\begin{tabular}{cccccc}
\hline Antibiotic & Inhibitory Mechanism & ST & & ST & \\
\hline & & w/o PA $\beta \mathbf{N}$ & w/ PA $\beta \mathbf{N}$ & w/o PA $\beta \mathbf{N}$ & w/ PA $\beta \mathbf{N}$ \\
\hline Ceftriaxone (CEF) & Cell wall synthesis & 0.25 & 0.125 & 0.25 & 0.25 \\
Chloramphenicol (CHL) & Protein synthesis & 8 & 2 & 8 & 2 \\
Ciprofloxacin (CIP) & DNA gyrase & 0.031 & 0.016 & 0.063 & 0.031 \\
Erythromycin (ERY) & Protein synthesis & 256 & 2 & 2 & 4 \\
Norfloxacin (NOR) & DNA gyrase & 4 & 4 & 512 & 64 \\
Tetracycline (TET) & Protein synthesis & 8 & & \\
\hline
\end{tabular}
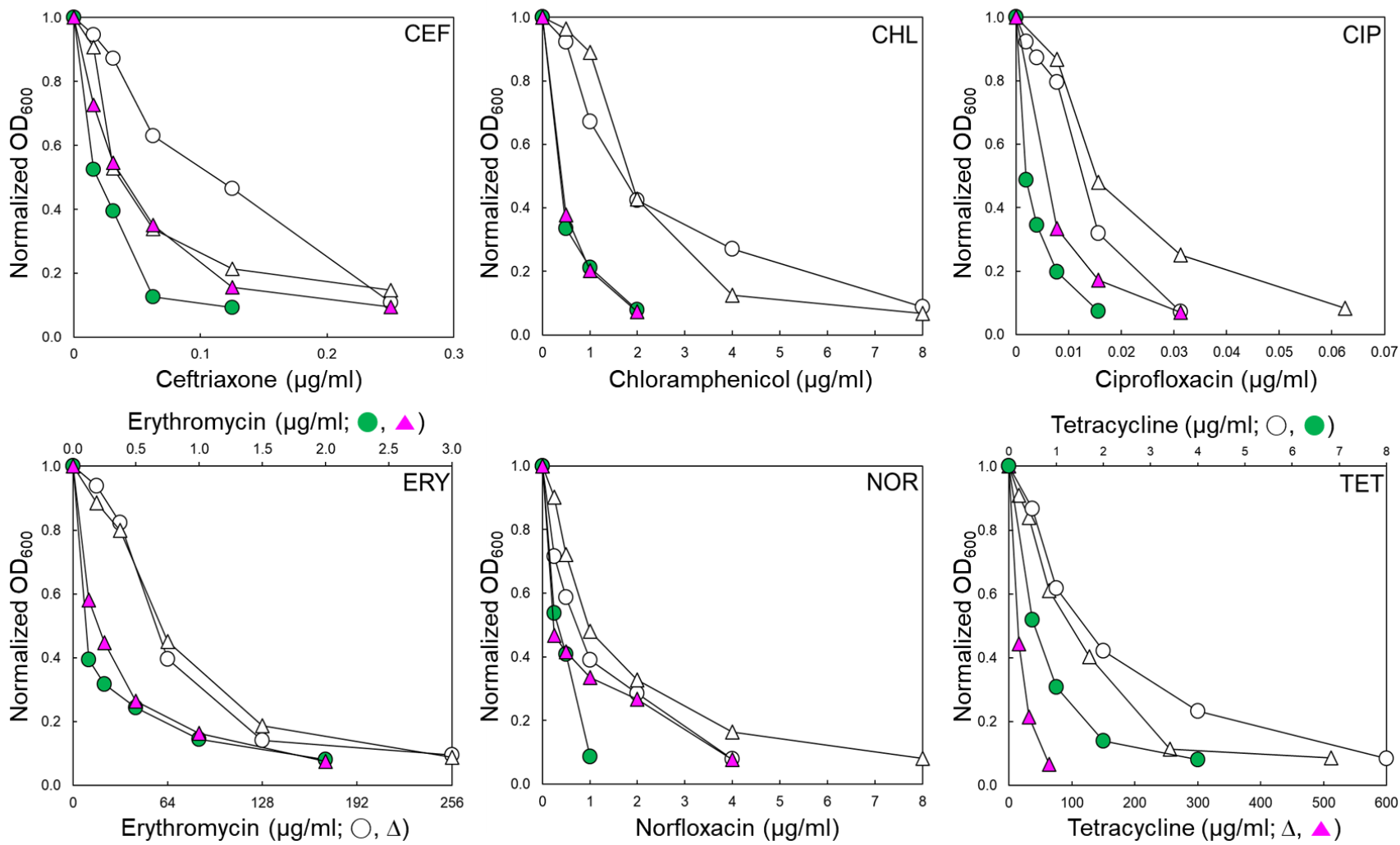

Figure 1. Antibiotic susceptibility of Salmonella Typhimurium ATCC $19585\left(\mathrm{ST}^{\mathrm{WT}} ; \circ\right.$, •) and clinically isolated antibiotic-resistant $S$. Typhimurium CCARM 8009 (ST $\left.{ }^{\mathrm{CI}} ; \Delta, \Delta\right)$ treated with ceftriaxone (CEF), chloramphenicol (CHL), ciprofloxacin (CIP), erythromycin (ERY), norfloxacin (NOR), and tetracycline (TET) in the absence $(\circ, \Delta)$ and presence $(\bullet, \mathbf{\Delta})$ of phenylalanine-arginine $\beta$-naphthylamide $(\operatorname{PA} \beta N)$.

\subsection{Biofilm-Forming Abilities of Salmonella Typhimurium Treated with Antibiotics in the Presence of $P A B N$}

The biofilm-forming abilities of $\mathrm{ST}^{\mathrm{WT}}$ and $\mathrm{ST}^{\mathrm{CI}}$ were evaluated at the sub-MICs of antibiotics, CEF (0.02 and $0.03 \mu \mathrm{g} / \mathrm{mL})$, CHL $(0.5 \mu \mathrm{g} / \mathrm{mL})$, CIP $(0.004$ and $0.008 \mu \mathrm{g} / \mathrm{mL})$, ERY $(0.5 \mu \mathrm{g} / \mathrm{mL})$, NOR $(0.25$ and $1 \mu \mathrm{g} / \mathrm{mL})$, and TET $(1$ and $8 \mu \mathrm{g} / \mathrm{mL})$, respectively, in the absence and presence of PA $\beta$ N. The sub-MICs of CEF, CHL, CIP, ERY, NOR, and TET were not effective on the inhibition of biofilm formation of $\mathrm{ST}^{\mathrm{WT}}$ and $\mathrm{ST}^{\mathrm{CI}}$, which were considerably inhibited in the presence of PA $\beta \mathrm{N}$ (Figure 2). The numbers of biofilm cells formed by $\mathrm{ST}^{\mathrm{WT}}$ and $\mathrm{ST}^{\mathrm{CI}}$ treated with antibiotics alone were approximately $8 \mathrm{log}$ $\mathrm{CFU} / \mathrm{cm}^{2}$. However, the addition of PA $\beta \mathrm{N}$ significantly decreased the biofilm-forming abilities of $\mathrm{ST}^{\mathrm{WT}}$ and $\mathrm{ST} \mathrm{T}^{\mathrm{CI}}$, showing the noticeable reductions in biofilm cell numbers when treated with $\mathrm{CEF}+\mathrm{PA} \beta \mathrm{N}, \mathrm{CHL}+\mathrm{PA} \beta \mathrm{N}, \mathrm{CIP}+\mathrm{PA} \beta \mathrm{N}, \mathrm{ERY}+\mathrm{PA} \beta \mathrm{N}, \mathrm{NOR}+\mathrm{PA} \beta \mathrm{N}$, and 
$\mathrm{TET}+\mathrm{PA} \beta \mathrm{N}$ (Figure 2). In addition, the biofilm-forming abilities of $\mathrm{ST}^{\mathrm{WT}}$ and $\mathrm{ST} \mathrm{T}^{\mathrm{CI}}$ were evaluated in the cell-free supernatant (CFS) of Chromobacterium violaceum-cultured media with or without $\mathrm{PA} \beta \mathrm{N}$. The number of $\mathrm{ST}^{\mathrm{WT}}$ and $\mathrm{ST}^{\mathrm{CI}}$ biofilm cells in $\mathrm{CFS}$ without $\mathrm{PA} \beta \mathrm{N}$ were 5.8 and $6.6 \log \mathrm{CFU} / \mathrm{cm}^{2}$, respectively, after $24 \mathrm{~h}$ of incubation at $37^{\circ} \mathrm{C}$, while the numbers of $\mathrm{ST}^{\mathrm{WT}}$ and $\mathrm{ST}^{\mathrm{CI}}$ biofilm cells in CFS were significantly decreased when treated with PA $\beta N$ (Figure 2).
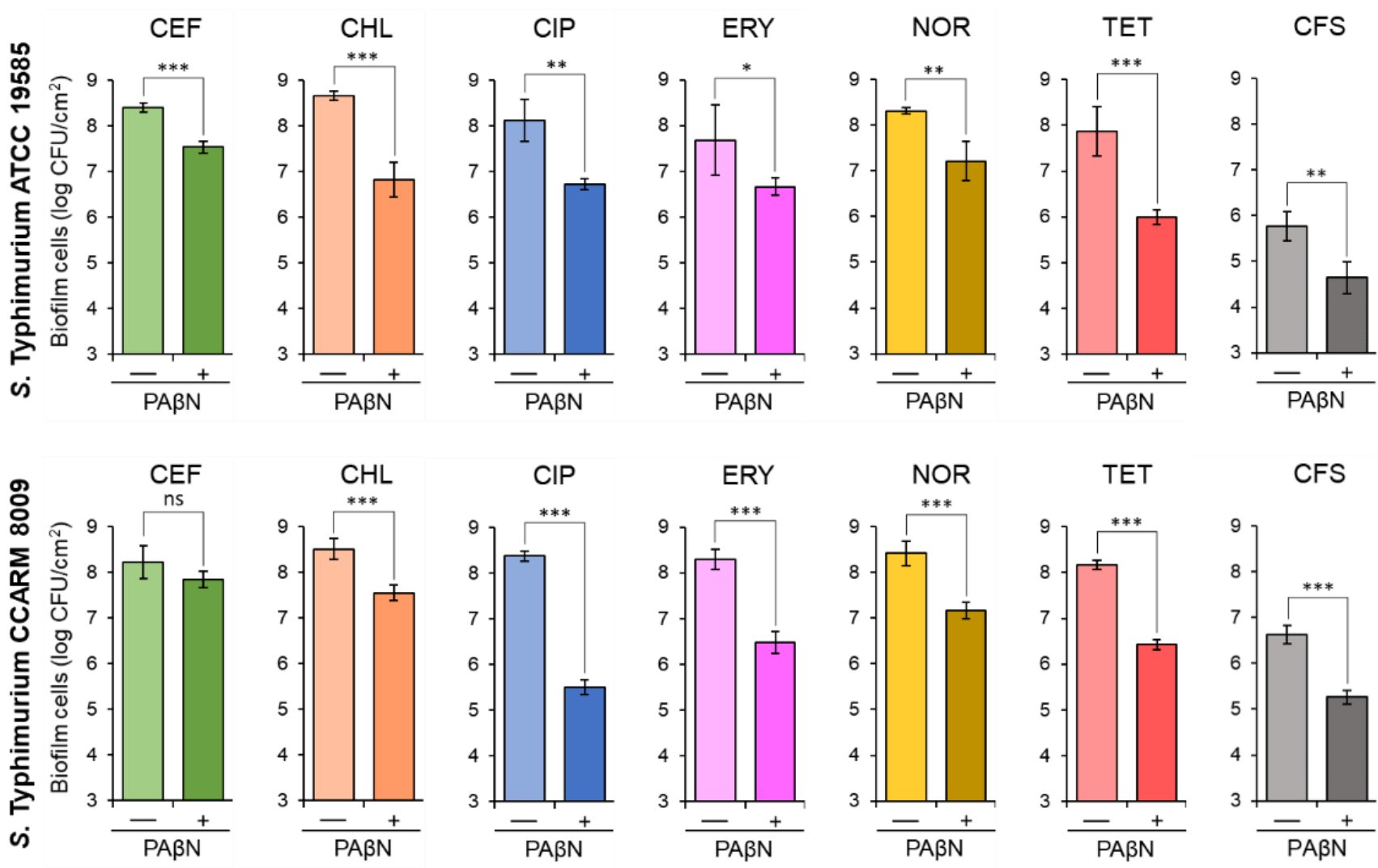

Figure 2. Biofilm-forming abilities of Salmonella Typhimurium ATCC 19585 (ST ${ }^{\mathrm{WT}}$ ) and clinically isolated antibiotic-resistant $S$. Typhimurium CCARM $8009\left(\mathrm{ST}^{\mathrm{CI}}\right)$ treated with $1 / 2 \mathrm{MIC}$ of ceftriaxone (CEF), chloramphenicol (CHL), ciprofloxacin (CIP), erythromycin (ERY), norfloxacin (NOR), and tetracycline (TET) in the absence $(-)$ and presence $(+)$ of phenylalanine-arginine $\beta$-naphthylamide $(\mathrm{PA} \beta \mathrm{N})$ and the biofilm-forming abilities of $\mathrm{ST}^{\mathrm{WT}}$ and $\mathrm{ST}^{\mathrm{CI}}$ in Chromobacterium violaceum-cultured cell-free supernatant (CFS) in the absence (-) and presence $(+)$ of PA $\beta N$. ns, ${ }^{*},{ }^{* *}$, and ${ }^{* *}$ indicate no significant difference $(p>0.05)$ and the significant difference between absence and presence of PA $\beta N$ at $p<0.05, p<0.01$, and $p<0.001$, respectively.

\subsection{Viability of Salmonella Typhimurium Treated with Antibiotic and PAßN}

The inhibitory effect of $1 / 2$ MICs of CEF $(0.125$ and $0.25 \mu \mathrm{g} / \mathrm{mL})$, CHL $(2$ and $8 \mu \mathrm{g} / \mathrm{mL})$, CIP $(0.015$ and $0.031 \mu \mathrm{g} / \mathrm{mL})$, ERY (64 and $128 \mu \mathrm{g} / \mathrm{mL})$, NOR ( 1 and $4 \mu \mathrm{g} / \mathrm{mL})$, and TET ( 4 and $256 \mu \mathrm{g} / \mathrm{mL}$ ) on the growth of $\mathrm{ST}^{\mathrm{WT}}$ and $\mathrm{ST}^{\mathrm{CI}}$, respectively, was evaluated in the CFS of C. violaceum-cultured media with or without PA $\beta N$ for $24 \mathrm{~h}$ at $37^{\circ} \mathrm{C}$. As shown in Figure 3, all antibiotic treatments significantly inhibited the growth of ST ${ }^{\mathrm{WT}}$ at the early stage of incubation $(<12 \mathrm{~h})$. The numbers of ST ${ }^{\mathrm{WT}}$ treated with CEF and CHL were increased at the late stage of incubation, showing 8.5 and $7.3 \log \mathrm{CFU} / \mathrm{cm}^{2}$ after $24 \mathrm{~h}$ of incubation, respectively. However, the antibiotic activities of CEF and CHL against $\mathrm{ST}^{\mathrm{WT}}$ were enhanced by $\mathrm{PA} \beta \mathrm{N}$, showing $7.0 \log \mathrm{CFU} / \mathrm{cm}^{2}$ at $\mathrm{CEF}+\mathrm{PA} \beta \mathrm{N}$ and $5.5 \log \mathrm{CFU} / \mathrm{cm}^{2}$ at $\mathrm{CHL}+\mathrm{PA} \beta \mathrm{N}$, respectively. Compared to the control, $\mathrm{CIP}+\mathrm{PA} \beta \mathrm{N}$ most effectively inhibited the growth of ST ${ }^{\mathrm{WT}}\left(3.4 \log \mathrm{CFU} / \mathrm{cm}^{2}\right)$ after $24 \mathrm{~h}$ of incubation. PA $\beta \mathrm{N}$ restored the antimicrobial activity of ERY against $\mathrm{ST}^{\mathrm{WT}}$, showing $4.2 \log \mathrm{CFU} / \mathrm{cm}^{2}$ at $12 \mathrm{~h}$ 
of incubation. However, the bacterial re-growth was observed for ERY and ERY $+P A \beta N$ at $24 \mathrm{~h}$ of incubation. ST ${ }^{\mathrm{WT}}$ was susceptible to NOR in the presence of PA $\beta \mathrm{N}$, showing the lowest number of $3.2 \log \mathrm{CFU} / \mathrm{cm}^{2}$. The growth of $S \mathrm{~T}^{\mathrm{WT}}$ was significantly decreased by TET (6.9 $\left.\log \mathrm{CFU} / \mathrm{cm}^{2}\right)$ and TET+PA $\beta \mathrm{N}\left(5.4 \log \mathrm{CFU} / \mathrm{cm}^{2}\right)$ at $8 \mathrm{~h}$ of incubation. However, the rapid growth of $\mathrm{ST}^{\mathrm{WT}}$ was observed at TET and TET+PA $\beta \mathrm{N}$ after $12 \mathrm{~h}$ of incubation, showing 7.8 and $6.5 \log \mathrm{CFU} / \mathrm{cm}^{2}$, respectively (Figure 3 ).
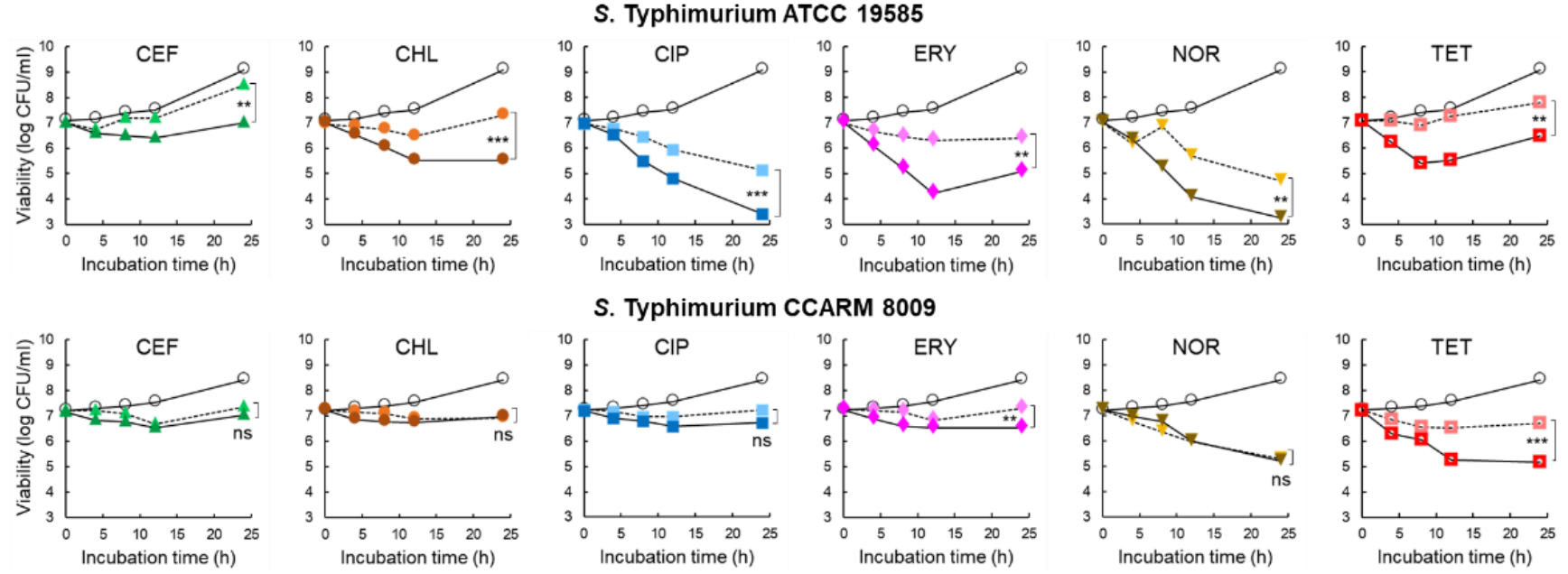

Figure 3. Survival of Salmonella Typhimurium ATCC $19585\left(\mathrm{ST}^{\mathrm{WT}}\right)$ and clinically isolated antibioticresistant $S$. Typhimurium CCARM $8009\left(\mathrm{ST}^{\mathrm{CI}}\right.$ ) treated with 1/2 MICs of ceftriaxone (CEF), chloramphenicol (CHL), ciprofloxacin (CIP), erythromycin (ERY), norfloxacin (NOR), and tetracycline (TET) in Chromobacterium violaceum-cultured cell-free supernatant (CFS) $[\bigcirc$; untreated control, without $(\Delta$, $\bullet, \square, \nabla, \nabla)$, and with $(\Delta, \bullet, \square, \diamond, \nabla, \square)$ phenylalanine-arginine $\beta$-naphthylamide $(\operatorname{PA} \beta N)] . n s,{ }^{* *}$, and ${ }^{* * *}$ indicate no significant difference $(p>0.05)$ and the significant difference between absence and presence of $\mathrm{PA} \beta \mathrm{N}$ at $p<0.05, p<0.01$, and $p<0.001$, respectively.

No significant difference in the antimicrobial activities was observed for CEF (7.3 $\left.\log \mathrm{CFU} / \mathrm{cm}^{2}\right)$ and $\mathrm{CEF}+\mathrm{PA} \beta \mathrm{N}\left(7.0 \mathrm{log} \mathrm{CFU} / \mathrm{cm}^{2}\right)$ against $\mathrm{ST}^{\mathrm{CI}}$ after $24 \mathrm{~h}$ of incubation. The numbers of $\mathrm{ST}^{\mathrm{CI}}$ had no significant difference between $\mathrm{CHL}$ and $\mathrm{CHL}+\mathrm{PA} \beta \mathrm{N}$ at the late stage of incubation, showing $7.0 \log \mathrm{CFU} / \mathrm{cm}^{2}$ at $24 \mathrm{~h}$ of incubation. Compared to the control, the significant decrease in the numbers of $\mathrm{ST}^{\mathrm{CI}}$ was observed at CIP and $\mathrm{CIP}+\mathrm{PA} \beta \mathrm{N}$ treatments, showing no significant difference between $\mathrm{CIP}\left(7.2 \log \mathrm{CFU} / \mathrm{cm}^{2}\right)$ and $\mathrm{CIP}+\mathrm{PA} \beta \mathrm{N}\left(6.7 \log \mathrm{CFU} / \mathrm{cm}^{2}\right)$ at $24 \mathrm{~h}$ of incubation. PA $\beta \mathrm{N}$ enhanced ERY activity and inhibited the growth of $\mathrm{ST}^{\mathrm{CI}}$ up to $24 \mathrm{~h}$ of incubation, showing $6.5 \mathrm{log} \mathrm{CFU} / \mathrm{cm}^{2}$ at $\mathrm{ERY}+\mathrm{PA} \beta \mathrm{N}$. Compared to the control, the growth of $\mathrm{ST}^{\mathrm{CI}}$ was rapidly decreased to 5.3 and $5.2 \log \mathrm{CFU} / \mathrm{cm}^{2}$ by NOR and NOR+PA $\beta \mathrm{N}$, respectively, after $24 \mathrm{~h}$ of incubation. The growth of $\mathrm{ST}^{\mathrm{CI}}$ was significantly decreased by TET+PA $\beta \mathrm{N}$ up to $12 \mathrm{~h}\left(5.2 \log \mathrm{CFU} / \mathrm{cm}^{2}\right)$, which is the most effective treatment to inhibit the growth of $\mathrm{ST}^{\mathrm{CI}}$, whereas the steady growth was observed after $12 \mathrm{~h}$ of incubation, showing $5.1 \log \mathrm{CFU} / \mathrm{cm}^{2}$ (Figure 3 ).

\subsection{Biofilm-Forming Ability, Motility, and Relative Fitness of Salmonella Typhimurium Cultured in Autoinducer-Containing Media}

The biofilm-forming abilities and the swimming motilities of ST ${ }^{\mathrm{WT}}$ and $\mathrm{ST}^{\mathrm{CI}}$ were evaluated in CFS when treated with CEF, CHL, CIP, FRY, NOR, and TET in the absence and presence of PA $\beta N$ (Figure 4). The biofilm-forming index $(\mathrm{BFI}<0.64)$ of $\mathrm{ST}^{\mathrm{WT}}$ at the combination treatments of antibiotics and PA $\beta \mathrm{N}$ was noticeably decreased when compared to antibiotic alone in the exception of CIP (Figure 4). The presence of PA $\beta N$ can enhance the anti-biofilm activity of CEF, CHL, CIP, ERY, NOR, and TET against ST ${ }^{\mathrm{WT}}$, showing the decrease in BFI to 0.32 at $C E F+P A \beta N, 0.44$ at $C H L+P A \beta N, 0.47$ at $C I P+P A \beta N, 0.41$ at $\mathrm{ERY}+\mathrm{PA} \beta \mathrm{N}$, less than 0.41 at $\mathrm{NOR}+\mathrm{PA} \beta \mathrm{N}$, and 0.53 at TET $+\mathrm{PA} \beta \mathrm{N}$, respectively. The 

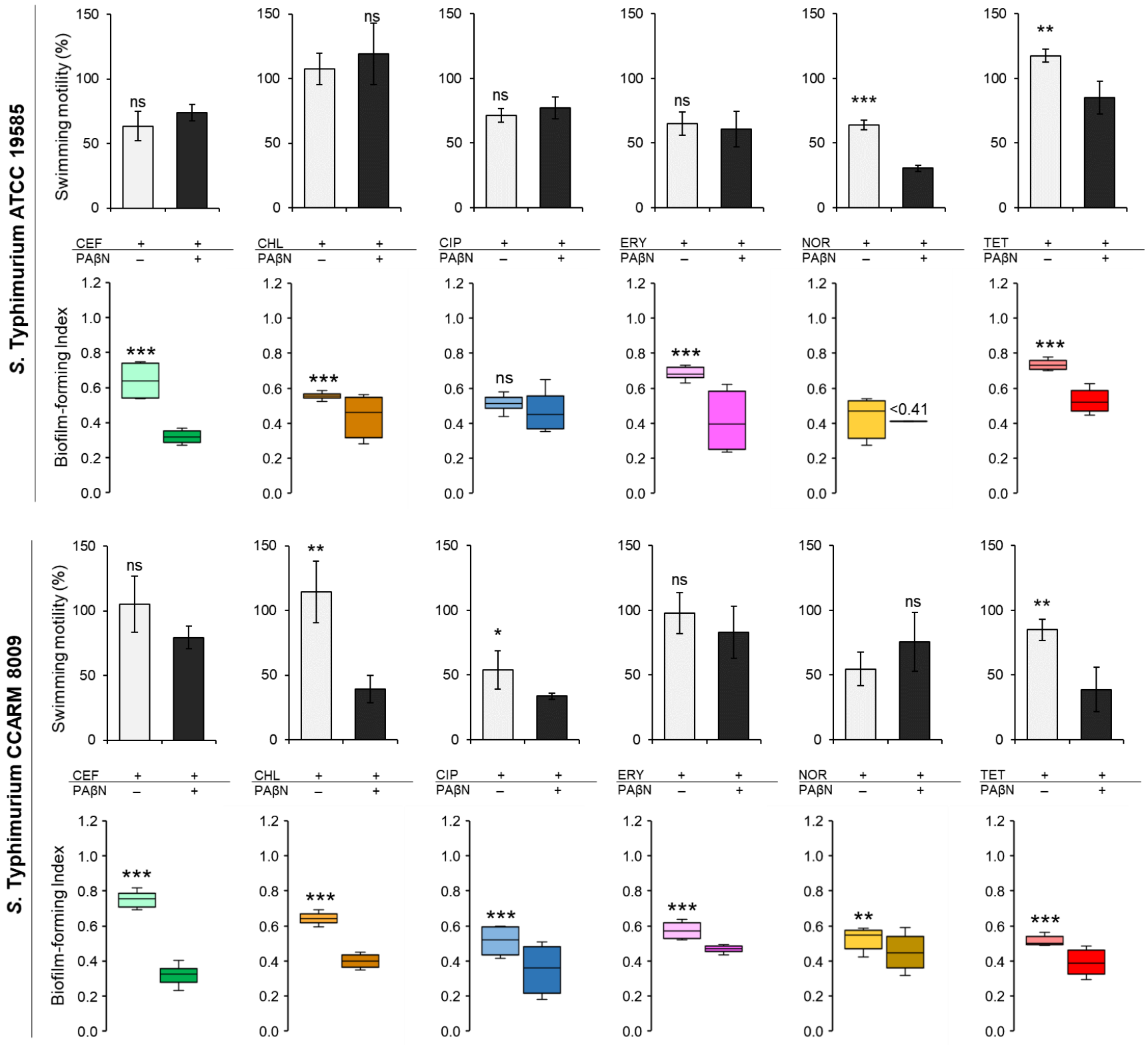

Figure 4. The biofilm-forming index (BFI) and swimming motility of Salmonella Typhimurium ATCC $19585\left(\mathrm{ST}^{\mathrm{WT}}\right)$ and clinically isolated antibiotic-resistant $S$. Typhimurium CCARM $8009\left(\mathrm{ST}^{\mathrm{CI}}\right)$ treated with 1/2 MICs of ceftriaxone (CEF), chloramphenicol (CHL), ciprofloxacin (CIP), erythromycin (ERY), norfloxacin (NOR), and tetracycline (TET) in Chromobacterium violaceum-cultured cell-free supernatant (CFS). (BFI in the absence $(\square, \square, \square, \square, \square, \square)$ and presence $(\square, \square, \square, \square, \square, \square)$ of phenylalaninearginine $\beta$-naphthylamide (PA $\beta N$ ) and swimming motility in the absence ( $\square$ ) and presence ( $\square$ ) of $\mathrm{Pa} \beta \mathrm{N}) . \mathrm{ns},{ }^{*}, * *$, and ${ }^{* * *}$ indicate no significant difference $(p>0.05)$ and the significant difference between the absence and presence of PA $\beta N$ at $p<0.05, p<0.01$, and $p<0.001$, respectively.

Compared to the control, the BFI of $\mathrm{ST}^{\mathrm{CI}}$ was decreased in the combination treatments of antibiotics and PA $\beta N$ (Figure 4). The BFI values of $\mathrm{ST}^{\mathrm{CI}}$ treated with $\mathrm{CEF}, \mathrm{CHL}, \mathrm{CIP}$, 
ERY, NOR, and TET were 0.75, 0.64, 0.51, 0.57, 0.53, and 0.51, respectively, while those were decreased to $0.32,0.40,0.35,0.47,0.45$, and 0.39 , respectively, after the combination treatments. Regardless of the absence and presence of $\mathrm{PA} \beta \mathrm{N}$, no significant differences in the swimming motility of $\mathrm{ST}^{\mathrm{CI}}$ were observed for each treatment, showing at $\mathrm{CEF}$ (24 mm), CEF+PA $\beta \mathrm{N}(18 \mathrm{~mm}), \mathrm{ERY}(22 \mathrm{~mm}), \mathrm{ERY}+\mathrm{PA} \beta \mathrm{N}(19 \mathrm{~mm}), \mathrm{NOR}(12 \mathrm{~mm})$, and $\mathrm{NOR}+\mathrm{PA} \beta \mathrm{N}(17 \mathrm{~mm})$. The significant decrease in swimming motility of $\mathrm{ST}^{\mathrm{CI}}$ was observed at CHL (26 mm), CHL+PA $\beta N(9 \mathrm{~mm}), \mathrm{CIP}(12 \mathrm{~mm}), \mathrm{CIP}+\mathrm{PA} \beta \mathrm{N}(8 \mathrm{~mm}), \mathrm{TET}(19 \mathrm{~mm})$, and $\mathrm{TET}+\mathrm{PA} \beta \mathrm{N}(9 \mathrm{~mm})$ (Figure 4$)$. The relative fitness levels of $\mathrm{ST}^{\mathrm{WT}}$ and $\mathrm{ST}^{\mathrm{CI}}$ treated with CEF, CHL, ERY, and TET were more than 0.9 and 0.7, respectively, which were decreased when treated with PA $\beta N$ (data not shown). The noticeable reduction in relative fitness of $\mathrm{ST}^{\mathrm{WT}}$ and $\mathrm{ST}^{\mathrm{CI}}$ was observed at $\mathrm{CIP}+\mathrm{PA} \beta \mathrm{N}$ and $\mathrm{NOR}+\mathrm{PA} \beta \mathrm{N}$.

\subsection{Correlation between Planktonic Growth and Biofilm Formation of Salmonella Typhimurium Treated with Antibiotics and PABN}

The correlation coefficients between the numbers of planktonic and biofilm cells of $\mathrm{ST}^{\mathrm{WT}}$ and $\mathrm{ST}^{\mathrm{CI}}$ were compared in the absence and presence of PA $\beta \mathrm{N}$ (Figure 5). The planktonic cell numbers were positively correlated with the biofilm cell numbers of ST ${ }^{\mathrm{WT}}$ $(r=0.89)$ and $\mathrm{ST}^{\mathrm{CI}}(r=0.72)$ in the absence of PA $\beta \mathrm{N}$. ST ${ }^{\mathrm{WT}}$ planktonic and biofilm cells in the presence of PA $\beta N$ were highly correlated at 0.70 . However, no correlation between $\mathrm{ST}^{\mathrm{CI}}$ planktonic cells and biofilm cells was observed in the presence of $\mathrm{PA} \beta \mathrm{N}(r=0.23)$.

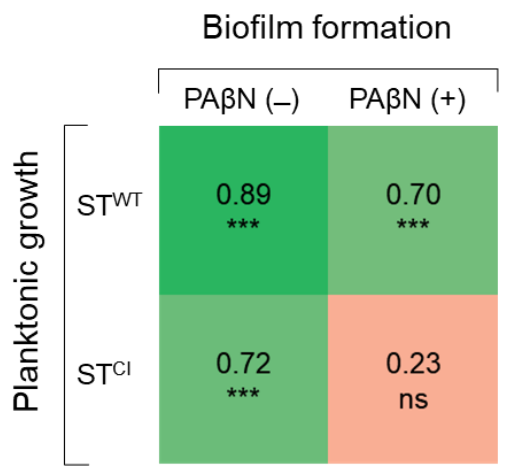

Figure 5. Correlation matrix of Pearson coefficients between planktonic cell count and biofilm cell counts $(n=24)$ of Salmonella Typhimurium ATCC $19585\left(\mathrm{ST}^{\mathrm{WT}}\right)$ and clinically isolated antibioticresistant $S$. Typhimurium CCARM $8009\left(\mathrm{ST}^{\mathrm{CI}}\right)$ in the absence and presence of PA $\beta N$. ns and ${ }^{* * *}$ indicate no significance $(p>0.05)$, significant difference at $p<0.05, p<0.01$, and $p<0.001$, respectively.

\section{Discussion}

This study describes the interplay between efflux pump activity and biofilm formation of $\mathrm{ST}^{\mathrm{WT}}$ and $\mathrm{ST}^{\mathrm{CI}}$. The bacterial efflux pumps are transmembrane transport proteins targeting multiple substrates, which are known as major determinants of multidrug resistance in bacteria [14]. The RND family is a major efflux pump system in Gram-negative bacteria, which is responsible for intrinsic and acquired resistance to various antibiotics. The AcrAB-TolC belonging to the RND efflux system is the most abundant efflux pump in $S$. Typhimurium [6]. The loss of AcrB in S. Typhimurium leads to the enhanced susceptibility to quinolones, tetracycline, and chloramphenicol, and the overexpression of $a c r B$ contributes to the reduced susceptibility to those antibiotics [15]. In general, AcrB is a substrate-binding trimer anchored in the inner membrane that extends into the periplasm and links with the outer membrane protein TolC, while AcrA is an accessory protein of the functional system [16]. AcrAB-TolC has a binding affinity to multi-substrates such as hydrophilic antibiotics and negatively charged $\beta$-lactams [17]. Therefore, the efflux pump systems contribute to the development of antibiotic resistance and also play an important role in the formation of bacterial biofilms $[5,13,18]$. Several studies have been reported that EPI could be used in a control strategy to inhibit biofilm formation $[18,19]$. The inhibition of efflux 
pumps can reduce biofilm formation by interfering with QS-mediated communication within and between strains [20-22]. PA $\beta N$, a broad-spectrum peptidomimetic inhibitor, inhibits RND efflux pump systems such as AcrAB-TolC of $S$. Typhimurium [13]. The PA $\beta N$ competitively binds to the hydrophobic trap of AcrA and AcrB to interrupt the substrate transport pathway [13]. Furthermore, membrane integrity and lipopolysaccharide (LPS) are major target-sites for PA $\beta \mathrm{N}$, specifically RND-type AcrAB-TolC and MexAB efflux pumps [14]. Therefore, the EPIs can potentiate antibiotic activity against antibiotic-resistant Gram-negative bacteria [23].

The MICs of CEF, CHL, CIP, ERY, NOR, and TET against $\mathrm{ST}^{\mathrm{WT}}$ and $\mathrm{ST}{ }^{\mathrm{CI}}$ were considerably decreased in the presence of PA $\beta N$ (Figure 1). These results confirm that the efflux pumps are involved in the intrinsic resistance of $S$. Typhimurium to several classes of antibiotics. This suggests that the antibiotic resistance in $S$. Typhimurium is associated with the substrate competition-dependent efflux systems [24]. The PA $\beta N$ noticeably enhanced the ERY activities against $\mathrm{ST} \mathrm{TT}^{\mathrm{WT}}$ and $\mathrm{ST} \mathrm{CI}^{\mathrm{CI}}$, suggesting that an intrinsic efflux pump activity might use ERY as substrate, leading to ERY resistance. This observation is in good agreement with a previous report that PA $\beta N$ exhibited the enhanced ERY susceptibility against Gram-negative bacteria [25]. The increased susceptibility to ERY may be attributed to the inhibition of RND efflux, MacAB-TolC, in the presence of $P A \beta N$, which is the main resistance mechanism of ERY in S. Typhimurium [26]. The antimicrobial activities of CIP, NOR, and TET against $\mathrm{ST}^{\mathrm{WT}}$ and $\mathrm{ST}^{\mathrm{CI}}$ were enhanced in the presence of PA $\beta \mathrm{N}$. This observation is in good agreement with a previous report that the MICs of quinolones and tetracyclines were decreased when treated with EPI [25]. Moreover, the deletion of AcrAB-TolC genes resulted in four-fold reduction in the MIC of chloramphenicol, suggesting that AcrAB and TolC proteins, which belong to RND efflux, are important for the development of antibiotic resistance of $S$. Typhimurium [27]. The overexpression of $m d f A$ and norE could contribute to fluoroquinolone resistance under the overproduction of RND and AcrAB-TolC. In general, the overproduction of AcrAB-TolC increases the MICs of several antibiotics against bacteria. In addition, tetracycline is transported by the MFS and RND efflux systems [28]. This suggests that the inhibition of the RND efflux pump system would be the major contribution to acquiring quinolones and tetracyclines resistance in $S$. Typhimurium. The major requirement for substrates of the RND efflux pump system is an insertion into the membrane bilayer. For instance, lipophilic side chains are likely to be partitioned into the lipid bilayer of the cytoplasmic membrane, being substrates of the RND efflux pump system [29]. Therefore, the EPIs could effectively enhance the susceptibility to lipophilic antibiotics including chloramphenicol, quinolone, macrolide, and tetracycline. Moreover, the efflux pumps belonging to the RND family are known, as the most effective efflux pump system extrude toxic compounds in $S$. Typhimurium [15]. Therefore, the competitive binding of PA $\beta N$ to the RND efflux pump can help control the multidrug-resistant bacteria.

Bacterial biofilms are highly resistant to environmental and chemical stresses such as heat, desiccation, acid, osmotic stress, food preservatives, disinfectants, and antibiotics [4]. The structural integrity of the complex biofilm matrix consisting of DNA, polysaccharides, and proteins provides membrane permeability barrier to antibiotics [30]. Indeed, biofilms are able to induce antibiotic resistance through several mechanisms including permeability disruption, starvation-stress response, and efflux pump activation [31]. In addition, the active efflux and diffusion can be involved in the transport of QS-signaling molecules, leading to the development of biofilm formation in Gram-negative bacteria [3]. The endogenous substrates of RND efflux pumps include fatty acids, natural antibiotics, QS-signaling molecules, and QS precursors $[6,32,33]$. In general, the biofilm formation of $S$. Typhimurium is regulated by cell communication process, which is called QS [34]. In a high cell density, bacteria produce and recognize QS-signaling acyl-homoserine lactones (AHLs), called autoinducer (AI), to coordinate gene expression [34]. The extrageneous AI-1 synthesized by various strains and Salmonella self-producing AI-2 can facilitate intraand interspecies communication within $S$. Typhimurium biofilms. Therefore, quorum quenching $(\mathrm{QQ})$ can be a possible approach to control bacterial biofilm formation in that $\mathrm{QS}$ 
inhibitors interrupt bacterial communication. Recently, the $Q Q$ has drawn more attention to enhance antibiotic susceptibility and eventually inhibit biofilm formation. The biofilmforming abilities of $\mathrm{ST}^{\mathrm{WT}}$ and $\mathrm{ST}^{\mathrm{CI}}$ were inhibited by CEF, CHL, CIP, ERY, NOR, and TET in the presence of PA $\beta N$ (Figure 2). The inhibition of biofilm-forming ability resulted in increased antibiotic activity because of the inactivation of efflux pumps developed in $\mathrm{ST}^{\mathrm{WT}}$ and $\mathrm{ST}^{\mathrm{CI}}$. The sub-MICs of CEF, CHL, CIP, ERY, NOR, and TET can increase the protein level in bacterial membrane compositions and exopolysaccharide production, leading to the antibiotic-induced biofilm formation [35]. However, the addition of PA $\beta N$ restored the antibiotic activity against $\mathrm{ST}^{\mathrm{WT}}$ and $\mathrm{ST} \mathrm{CI}^{\mathrm{C}}$ (Figure 2). This suggests that the efflux pumps can use QS-signaling molecules as substrates and eventually inhibit the biofilm formation of $S$. Typhimurium. The deletion of efflux pump-related genes such as $a c r B$ and $t o l C$ could cause the loss of curli and extracellular matrix production [36]. The CEF activity against ST ${ }^{\mathrm{WT}}$ and $\mathrm{ST}^{\mathrm{CI}}$ was increased in the presence of $\mathrm{PA} \beta \mathrm{N}$ (Figure 2). This is in good agreement of previous report that $A B C$ transporter is involved in the resistance to $\beta$-lactam antibiotics, corresponding to the role of AcrAB-TolC in the enhanced resistance to $\beta$-lactam antibiotics [37]. In addition, the RND-type efflux pump, MdsABC, has a broad substrate range, including chloride, cephalosporin, chloramphenicol, and novobiocin [38]. Therefore, the RND efflux pump plays a major role in biofilm formation [16]. The efflux pump-assisted biofilm formation is attributed to the expulsion of extracellular polymeric substances (EPSs) and QS signaling molecules, the regulation of biofilm-related genes, efflux of toxic components, and prevention of cell-to-cell and cell-to-surface adhesion [13,39]. This implies that the RND efflux pump inhibited by PA $\beta N$ could retard the biofilm formation. The $\mathrm{CIP}+\mathrm{PA} \beta \mathrm{N}$ and NOR+PA $\beta \mathrm{N}$ decreased the biofilm-forming abilities of $\mathrm{ST}^{\mathrm{WT}}$ and $\mathrm{ST}^{\mathrm{CI}}$ (Figure 2). The QeqA and OqxAB sharing homology with AcrAB and MexAB efflux systems have the ability to hydrolyze fluoroquinolones [40]. Therefore, the reduced biofilm numbers in $\mathrm{ST}^{\mathrm{WT}}$ and $\mathrm{ST}^{\mathrm{CI}}$ treated with CIP or NOR and PA $\beta \mathrm{N}$ might be attributed to QeqA and OqxAB that are specific for fluoroquinolone. This suggests that $P A \beta N$ could reduce quinolone resistance and restore the quinolone antibiotic activity against Gram-negative bacteria [41]. Moreover, the addition of PA $\beta N$ also increased the anti-biofilm activity of CHL, ERY, and TET. The reduced biofilm numbers of $\mathrm{ST}^{\mathrm{WT}}$ and $\mathrm{ST}^{\mathrm{CI}}$ treated with $\mathrm{CHL}$, ERY, and TET in the presence of PA $\beta N$ might be due to the inhibition of mexAB-oprM. This observation implied that the mexAB-oprM efflux pump system is linked to intrinsic resistance to antibiotics such as chloramphenicol, quinolones, macrolides, and tetracycline [42]. MexAB-OprM and MexEF-OprN in Gram-negative bacteria can transport intercellular signals or intermediates during biofilm formation [43]. Therefore, the inhibition of efflux pumps might be a good strategy to effectively inhibit biofilm formation.

Gram-negative bacteria synthesize various $N$-acyl homoserine lactones (AHLs) in a cell density-dependent manner [44]. In this study, Salmonella can detect AHLs produced by C. violaecium [45]. Salmonella spp. cannot synthesize their own AHLs because of the absence of a luxI homolog but can recognize external AHLs by the receptor, SdiA [44]. The results as given in Figure 2 imply that the biofilm numbers were reduced in CFS containing AHLs when treated with PA $\beta N$. This observation suggests that PA $\beta N$ blocked the transport of AHLs into ST ${ }^{\mathrm{WT}}$ and $\mathrm{ST}{ }^{\mathrm{CI}}$, leading to the inhibition of biofilm formation. The RND efflux pump can extrude AHLs such as $3 \mathrm{OC}_{12}$-HSL [46]. For instance, MexCD-OprJ can extrude AIs, resulting in the reduced accumulation of AIs in the bacterial cell [46]. Thus, the inhibition of efflux pumps could affect the AHL transport, leading to the reduced expression of AHL-based QS genes and decrease in biofilm formation.

The sub-MICs of CEF, CHL, CIP, ERY, NOR, and TET could not inhibit the growth of $\mathrm{ST}^{\mathrm{WT}}$ and $\mathrm{ST}^{\mathrm{CI}}$. No significant differences in the bacterial numbers between the control and antibiotic treatments (Figure 3). The growths of CEF-, CHL-, ERY-, NOR-, and TETinjured ST ${ }^{\mathrm{WT}}$ and CEF-, CHL-, CIP-, and ERY-stressed ST ${ }^{\mathrm{CI}}$ were recovered after $12 \mathrm{~h}$, but the recovery rates were significantly lowered in the presence of PA $\beta N$. The growths of $\mathrm{ST}^{\mathrm{WT}}$ and $\mathrm{ST}^{\mathrm{CI}}$ were most effectively inhibited by the antibiotics combined with PA $\beta \mathrm{N}$ throughout the incubation period. The decrease in the numbers of bacteria treated with 
the combination of antibiotics and EPI suggests that the efflux pumps are associated with the innate resistance in $S$. Typhimurium. However, the mechanisms of resistance of bacteria to $\beta$-lactams and chloramphenicol are also associated with $\beta$-lactamases-mediated hydrolysis, porin channels, and efflux pump activity [47]. The change in the porin channel influences membrane permeability as an access barrier to antibiotics such as $\beta$-lactams and quinolones [47]. The growths of $\mathrm{ST}^{\mathrm{CI}}$ treated with $\mathrm{CEF}, \mathrm{CEF}+\mathrm{PA} \beta \mathrm{N}, \mathrm{CHL}$, and CHL+PA $\beta \mathrm{N}$ were steady constant regardless of the levels of efflux pump activities (Figure 3). Compared to the control, the numbers of $\mathrm{ST}^{\mathrm{WT}}$ and $\mathrm{ST}^{\mathrm{CI}}$ treated with CIP, ERY, and TET were reduced in the presence of PA $\beta \mathrm{N}$ up to $12 \mathrm{~h}$ of incubation (Figure 4 ). This result implies that the efflux pump can extrude antibiotics such as macrolides, tetracyclines, and quinolones as substrates. Moreover, the mechanism of resistance of bacteria to fluoroquinolones is caused by mutations in DNA-gyrase and topoisomerase IV, altered permeability, and active efflux pump [48]. The fluoroquinolone efflux pump system of $S$. Typhimurium is encoded by the AcrAB homologous protein [49]; thus, PA $\beta N$ can effectively enhance the antibiotic activities of CIP and NOR against $\mathrm{ST}^{\mathrm{WT}}$ and $\mathrm{ST}^{\mathrm{CI}}$ (Figure 3 ).

The biofilm-forming abilities of $\mathrm{ST}^{\mathrm{WT}}$ and $\mathrm{ST}^{\mathrm{CI}}$ in CFS containing AHLs are shown in Figure 4. The combination treatments of antibiotics and PA $\beta N$ showed a lower biofilmforming index (BFI) than the single antibiotic treatments (Figure 4). The combination of antibiotics and PA $\beta N$ can synergistically inhibit QS, resulting in the inhibition of biofilm formation. This observation is in good agreement with previous study that the combinations of EPI with fluoroquinolones effectively inhibited QS and biofilm formation [50]. The inhibition of efflux pump in CFS media may be related to the decrease in transport of AHLs, leading to the inhibition of biofilm formation. The lowest BFI was observed in ST treated with $\mathrm{CEF}+\mathrm{PA} \beta \mathrm{N}(0.32)$, which was followed by $\mathrm{CIP}+\mathrm{PA} \beta \mathrm{N}(0.35)$ and TET $+\mathrm{PA} \beta \mathrm{N}$ (0.39) (Figure 4). This indicates that EPIs are effective at inhibiting biofilm formation under low concentrations of antibiotics and even enhance the therapeutic potential of low doses of antibiotics. The extrusion of QS-signaling molecules causes an increased concentration of extracellular self-inducers, leading to serious bacterial infection [51]. Thus, certain efflux pumps have a role in modifying both the QS response and pathogenicity in bacteria [18]. In addition, during the infection, pathogenic bacteria can produce a variety of virulence factors such as toxins, outer membrane proteins, or biofilm to invade the host or evade the host immune system [52]. Among virulence factors produced by Gramnegative bacteria, the production of QS-regulated virulence factors plays an important role in biofilm formation. For example, the production of pyocyanin and rhamnolipids from the QS system is responsible for the deposition of extracellular DNA [19]. This indicates that the high efflux pump activity may promote the QS system, leading to the synthesis of several virulence factors and the increase in bacterial pathogenicity. This confirms that the bacterial efflux pumps and QS system are involved in the regulation of biofilm formation. Therefore, the inhibition of bacterial efflux pumps can restore antibiotic activity, leading to the disruption of biofilm formation [14].

$\mathrm{ST}^{\mathrm{WT}}$ treated with $\mathrm{NOR}+\mathrm{PA} \beta \mathrm{N}$ showed the lowest motility when compared to other treatments (Figure 4). At the early stages of biofilm formation, swimming motility plays an important role in bacterial translocation and adhesion to the surface [53]. This indicates that the reduced motility in the presence of $P A \beta N$ may result in the decreased ability of $\mathrm{ST}^{\mathrm{WT}}$ to form biofilms. However, the lowest swimming motility of $\mathrm{ST}^{\mathrm{CI}}$ was observed at $\mathrm{CIP}+\mathrm{PA} \beta \mathrm{N}$, but the lowest BFI was observed at CEF+PA $\beta \mathrm{N}$ (Figure 4). This implies that the swimming motility was not directly correlated with the biofilm-forming ability of $\mathrm{ST}^{\mathrm{CI}}$ in the presence of $\mathrm{PA} \beta \mathrm{N}$. The relative fitness levels of ST ${ }^{\mathrm{WT}}$ and $\mathrm{ST}^{\mathrm{CI}}$ treated with antibiotics were comparably decreased in the presence of $\mathrm{PA} \beta \mathrm{N}$, in other words reflecting the increase in fitness cost. In general, bacteria can quickly adapt to new challenges and subsequently continue to optimize their fitness [54]. The antibiotic-resistant bacteria have relatively low fitness under favorable conditions [55]. In addition, bacteria with low efflux pump activity might have a higher fitness cost than bacteria with high efflux pump activity [56]. In particular, genes involved in peptidoglycan synthesis or efflux 
control were detected more often in populations with low fitness [57]. Therefore, bacteria with a low fitness cost are more likely to develop antibiotic resistance because of a fitness advantage [54]. Furthermore, the accumulation of compensatory mutations can restore the bacterial fitness and decrease the fitness cost in antibiotic-resistant bacteria [58]. Thus, the fitness cost is associated with bacterial evolution and the maintenance of antibiotic resistance. The planktonic cell and biofilm cell numbers of ST ${ }^{\mathrm{WT}}(r=0.89)$ and ST $(r=0.72)$ were highly correlated in the absence of PA $\beta N$. The numbers of active planktonic cells are associated with the surface-attached growth during biofilm maturation [59]. The adhesion of planktonic cells to an abiotic or biotic surface is critical at the early stage of biofilm formation [60]. The efflux pumps may be involved in biofilm formation such as the transport of extracellular polymeric substances (EPS) or QS signaling to facilitate biofilm matrix formation. Therefore, the inhibition of an efflux pump could also inhibit biofilm formation. No significant correlation was observed between $\mathrm{ST}^{\mathrm{CI}}$ planktonic and biofilm cell numbers in the presence of PA $\beta N(r=0.23)$. This result suggests that the viability of planktonic cells was not influenced by $\mathrm{Pa} \beta \mathrm{N}$, and the reduction in the biofilm cells was related to the inhibition of efflux pump developed in $\mathrm{ST}^{\mathrm{CI}}$.

\section{Materials and Methods}

\subsection{Bacterial Strains and Culture Conditions}

Strains of Salmonella enterica subsp. enterica serovar Typhimurium ATCC 19585 (ST ${ }^{\mathrm{WT}}$ ) and clinically isolated antibiotic-resistant $S$. Typhimurium CCARM $8009\left(\mathrm{ST}^{\mathrm{CI}}\right)$ were obtained from the American Type Culture Collection (ATCC; Manassas, VA, USA) and the Culture Collection of Antibiotic Resistant Microbes (CCARM; Seoul, Korea), respectively. Chromobacterium violaceum KACC 11542 was obtained from the Korean Agricultural Culture Collection (KACC; Seoul, Korea). Strains of $\mathrm{ST}^{\mathrm{WT}}$ and $\mathrm{ST}^{\mathrm{CI}}$ were cultivated in trypticase soy broth (TSB; Difco, BD, Sparks, MD, USA) at $37^{\circ} \mathrm{C}$ for $20 \mathrm{~h}$. C. violaceum was cultivated in Luria-Bertani (LB; Difco, BD, Sparks, MD, USA) broth at $26^{\circ} \mathrm{C}$ for $20 \mathrm{~h}$. The cultured cells were harvested by centrifugation at $6000 \times g$ for $10 \mathrm{~min}$ and diluted with phosphate-buffered saline (PBS, $\mathrm{pH} 7.2$ ) to approximately $10^{8} \mathrm{CFU} / \mathrm{mL}$ for assays.

\subsection{Antibiotic Susceptibility Assay}

The susceptibilities of ST ${ }^{\mathrm{WT}}$ and $\mathrm{ST}^{\mathrm{CI}}$ to antibiotics and efflux pump inhibitor (EPI) were determined according to the Clinical Laboratory Standards Institute procedure with minor modifications [61]. Antibiotics (Table 1) including ceftriaxone (CEF), chloramphenicol (CHL), ciprofloxacin (CIP), erythromycin (ERY), norfloxacin (NOR), tetracycline (TET), and EPI (phenylalanine-arginine $\beta$-naphthylamide, PA $\beta N$ ) were purchased from Sigma Aldrich Chemicals (St. Louis, MO, USA). Antibiotic and EPI stock solutions were prepared by dissolving in sterile distilled water (CEF), ethanol (CHL, ERY, and TET), glacial acetic acid (CIP and NOR), and methanol $(P A \beta N)$, respectively, at a concentration of $10.24 \mathrm{mg} / \mathrm{mL}$. Each antibiotic stock solution $(100 \mu \mathrm{L})$ was serially $(1: 2)$ diluted to concentrations ranging from 512 to $0.015 \mu \mathrm{g} / \mathrm{mL}$ in fresh TSB without and with PA $\beta \mathrm{N}$ at the pre-determined sub-minimum inhibitory concentrations (sub-MIC; $120 \mu \mathrm{g} / \mathrm{mL}$ ) in 96-well microtiter plates (BD Falcon, San Jose, CA, USA). Each strain $\left(10^{5} \mathrm{CFU} / \mathrm{mL}, 100 \mu \mathrm{L}\right)$ was inoculated in the diluted antibiotic with EPI (1:2) and incubated at $37^{\circ} \mathrm{C}$ for $18 \mathrm{~h}$ to determine MIC defined as the lowest concentrations of antibiotics where no visible bacterial growths were observed.

\subsection{Biofilm-Forming Ability Assay}

The biofilm-forming abilities of ST ${ }^{\mathrm{WT}}$ and ST ${ }^{\mathrm{CI}}\left(10^{6} \mathrm{CFU} / \mathrm{mL}\right.$ each) treated with CEF, CHL, CIP, ERY, NOR, and TET were evaluated in the absence and presence of PA $\beta N$ $(120 \mu \mathrm{g} / \mathrm{mL})$. The concentrations were determined at the 1/2 MICs of all antibiotics in the presence of PA $\beta \mathrm{N}$, including CEF $(0.0625$ and $0.125 \mu \mathrm{g} / \mathrm{mL}), \mathrm{CHL}(1$ and $1 \mu \mathrm{g} / \mathrm{mL}), \mathrm{CIP}$ $(0.0078$ and $0.0156 \mu \mathrm{g} / \mathrm{mL})$, ERY $(1$ and $1 \mu \mathrm{g} / \mathrm{mL})$, NOR $(0.5$ and $2 \mu \mathrm{g} / \mathrm{mL})$, and TET (2 and $32 \mu \mathrm{g} / \mathrm{mL}$ ) against $\mathrm{ST}^{\mathrm{WT}}$ and $\mathrm{ST}^{\mathrm{CI}}$, respectively. The biofilm cells were enumerated using a swabbing method with slight modification $[62,63]$. The test strains were also cultured 
in C. violaceum-cultured cell-free supernatant (CFS) in the absence and presence of PA $\beta N$ $(120 \mu \mathrm{g} / \mathrm{mL})$. In brief, after $24 \mathrm{~h}$ of incubation at $37^{\circ} \mathrm{C}$, the biofilm cells were collected from the 96-well microtiter plates. Each well of the 96-well microtiter plate was gently rinsed two times with PBS to remove planktonic cells and scraped using a water-moistened sterile cotton swab. The collected biofilm cells harvested by centrifugation at $5000 \times g$ for 10 min at $4{ }^{\circ} \mathrm{C}$ were serially (1:10) diluted with PBS, plated on the TSA using an Autoplate ${ }^{\circledR}$ Spiral Plating System (Spiral Biotech Inc., Norwood, MA, USA) and incubated at $37{ }^{\circ} \mathrm{C}$ for $24 \mathrm{~h}$. The biofilm cell numbers were enumerated using a QCount ${ }^{\circledR}$ Colony Counter (Spiral Biotech Inc.).

\subsection{Growth-Based Bacterial Viability Assay}

The antimicrobial activities of single antibiotic and combination treatments of antibiotics and $\mathrm{PA} \beta \mathrm{N}$ against $\mathrm{ST}^{\mathrm{WT}}$ and $\mathrm{ST}^{\mathrm{CI}}$ were evaluated in TSB at $37^{\circ} \mathrm{C}$ for $24 \mathrm{~h}$. The initial population $\left(10^{7} \mathrm{CFU} / \mathrm{mL}\right)$ of $\mathrm{ST}^{\mathrm{WT}}$ and $\mathrm{ST}^{\mathrm{CI}}$ was inoculated at $37^{\circ} \mathrm{C}$ in C. violaceum-cultured CFS with $1 / 2$ MICs of antibiotics in the absence and presence of PA $\beta N(120 \mu \mathrm{g} / \mathrm{mL})$. The antibiotics concentrations were $0.125 \mu \mathrm{g} / \mathrm{mL}$ CEF, $4 \mu \mathrm{g} / \mathrm{mL}$ CHL, $0.0156 \mu \mathrm{g} / \mathrm{mL}$ CIP, $128 \mu \mathrm{g} / \mathrm{mL}$ ERY, $2 \mu \mathrm{g} / \mathrm{mL}$ NOR, and $4 \mu \mathrm{g} / \mathrm{mL}$ TET for ST ${ }^{\mathrm{WT}}$ in absence of PA $\beta \mathrm{N}$, $0.0625 \mu \mathrm{g} / \mathrm{mL}$ CEF, $1 \mu \mathrm{g} / \mathrm{mL}$ CHL, $0.0078 \mu \mathrm{g} / \mathrm{mL}$ CIP, $1 \mu \mathrm{g} / \mathrm{mL}$ ERY, $0.5 \mu \mathrm{g} / \mathrm{mL}$ NOR, and $2 \mu \mathrm{g} / \mathrm{mL}$ TET for ST ${ }^{\mathrm{WT}}$ in presence of PA $\beta \mathrm{N}, 0.125 \mu \mathrm{g} / \mathrm{mL} \mathrm{CEF}, 4 \mu \mathrm{g} / \mathrm{mL}$ CHL, $0.03125 \mu \mathrm{g} / \mathrm{mL} \mathrm{CIP}, 128 \mu \mathrm{g} / \mathrm{mL}$ ERY, $4 \mu \mathrm{g} / \mathrm{mL} \mathrm{NOR}$, and $256 \mu \mathrm{g} / \mathrm{mL}$ TET for ST ${ }^{\mathrm{CI}}$ in the absence of PA $\beta \mathrm{N}$, and $0.125 \mu \mathrm{g} / \mathrm{mL} \mathrm{CEF,} 1 \mu \mathrm{g} / \mathrm{mL}$ CHL, $0.0156 \mu \mathrm{g} / \mathrm{mL} \mathrm{CIP,} 1 \mu \mathrm{g} / \mathrm{mL}$ ERY, $2 \mu \mathrm{g} / \mathrm{mL}$ NOR, and $32 \mu \mathrm{g} / \mathrm{mL}$ TET for ST ${ }^{\mathrm{CI}}$ in the presence of PA $\beta \mathrm{N}$. The inoculated samples were incubated for $0,4,8,12$, and $24 \mathrm{~h}$ at $37{ }^{\circ} \mathrm{C}$. After incubation, the collected planktonic cells were serially (1:10) diluted with PBS. Proper dilutions were plated on the TSA and incubated at $37^{\circ} \mathrm{C}$ for $24 \mathrm{~h}$. Viable cell numbers were enumerated as described above.

\subsection{Biofilm-Forming Ability in CFS}

$\mathrm{ST}^{\mathrm{WT}}$ and $\mathrm{ST}^{\mathrm{CI}}\left(10^{7} \mathrm{CFU} / \mathrm{mL}\right.$ each) were cultured in C. violaceum-cultured CFS with $1 / 2$ MICs of CEF, CHL, CIP, ERY, NOR, and TET with and without PA $\beta N(120 \mu \mathrm{g} / \mathrm{mL})$ in a 96-well plate. After incubation at $37^{\circ} \mathrm{C}$ for $24 \mathrm{~h}$, the cultures were centrifuged at $5000 \times g$ for $10 \mathrm{~min}$ at $4{ }^{\circ} \mathrm{C}$ to collect planktonic cells. Each well was rinsed with PBS, and biofilm cells were collected by using a cotton swab and centrifuged at $5000 \times \mathrm{g}$ for $10 \mathrm{~min}$ at $4{ }^{\circ} \mathrm{C}$. The planktonic and biofilm cells were enumerated as described above. The biofilm-forming index (BFI) was expressed as the ratio of number of planktonic cells to that of biofilm cells [64].

\subsection{Swimming Motility Assay}

Flagellum-dependent movement was determined by the swimming motility assay [65]. $\mathrm{ST}^{\mathrm{WT}}$ and ST ${ }^{\mathrm{CI}}$ cells were treated with $1 / 2 \mathrm{MIC}$ of CEF, CHL, CIP, ERY, NOR, and TET in the presence and absence of PA $\beta \mathrm{N}(120 \mu \mathrm{g} / \mathrm{mL})$ and incubated at $37{ }^{\circ} \mathrm{C}$ for $24 \mathrm{~h}$. The planktonic cells $\left(5 \mathrm{~mL} ; 10^{3} \mathrm{CFU} / \mathrm{mL}\right)$ were collected and seeded onto the center of the surface of $0.3 \%$ agar-containing plates. After $12 \mathrm{~h}$ of incubation at $37^{\circ} \mathrm{C}$, the bacterial migration on each plate was measured using a digital vernier caliper (The L.S. Starrett Co., Athol, MA, USA).

\subsection{Measurement of Relative Fitness}

The relative fitness was estimated to assess the cost of resistance of ST ${ }^{\mathrm{WT}}$ and ST ${ }^{\mathrm{CI}}$ cells treated with 1/2 MICs of CEF, CHL, CIP, ERY, NOR, and TET in the presence and absence of PA $\beta N(120 \mu \mathrm{g} / \mathrm{mL})$ for $24 \mathrm{~h}$. Then, the antibiotic-treated planktonic cells were collected by centrifugation at $5000 \times g$ for $10 \mathrm{~min}$ at $4{ }^{\circ} \mathrm{C}$, rinsed two times with PBS, and cultured at $37^{\circ} \mathrm{C}$ for $24 \mathrm{~h}$ in fresh TSB in the absence of antibiotics and PA $\beta \mathrm{N}$. The relative fitness was expressed as the ratio of the growth $\left(\mathrm{OD}_{600}\right)$ of treated cells to that of untreated control in the absence of antibiotics. 


\subsection{Statistical Analysis}

All experiments were carried out in duplicate on three replicates. Data were analyzed using the Statistical Analysis System (SAS). The general linear model (GLM) and Fisher's least significant difference (LSD) procedures were used to determine significant differences between treatments at $p<0.05, p<0.01$, and $p<0.001$. The correlations between planktonic and biofilm cells were evaluated using Pearson's correlation coefficient.

\section{Conclusions}

This study highlights the effect of efflux pump activity on the biofilm formation of $S$. Typhimurium. The most significant findings were that (1) the MICs of CEF, CHL, CIP, ERY, NOR, and TET against $\mathrm{ST}^{\mathrm{WT}}$ and $\mathrm{ST}{ }^{\mathrm{CI}}$ were decreased in the presence of $\mathrm{PA} \beta \mathrm{N}$, (2) the sub-MICs of CEF, CHL, CIP, ERY, NOR, and TET were not effective in the inhibition of biofilm formation of $\mathrm{ST}^{\mathrm{WT}}$ and $\mathrm{ST}^{\mathrm{CI}}$ and, (3) $\mathrm{PA} \beta \mathrm{N}$ significantly increased the inhibitory activity of sub-MICs of CEF, CHL, CIP, ERY, NOR, and TET on the biofilm formation by $\mathrm{ST}^{\mathrm{WT}}$ and $\mathrm{ST} \mathrm{T}^{\mathrm{CI}}$. The NOR+PA $\beta \mathrm{N}$ and $\mathrm{CEF}+\mathrm{PA} \beta \mathrm{N}$ treatments showed the highest antibiofilm activity against $\mathrm{ST} \mathrm{T}^{\mathrm{WT}}$ and $\mathrm{ST} \mathrm{T}^{\mathrm{CI}}$, respectively. The inhibition of efflux pump by EPIs can interfere with the transport of quorum-sensing molecules, leading to the decrease in biofilm-forming abilities of pathogens. PaßN have no effect on the viability of planktonic cells but only inhibited biofilm formation. The use of antibiotics combined with EPIs has a great potential of controlling biofilm formation. Accordingly, EPIs can be used as a potential control agent to inhibit biofilm formation by pathogens.

Author Contributions: J.D. and Y.L. conducted all experiments and also wrote the manuscript. F.L., X.H. and J.A. designed the experiment and contributed to the data analysis. All authors have read and agreed to the published version of the manuscript.

Funding: This research was supported by Basic Science Research Program through the National Research Foundation of Korea (NRF) funded by the Ministry of Education (NRF-2016R1D1A3B01008304).

Institutional Review Board Statement: Not applicable.

Informed Consent Statement: Not applicable.

Data Availability Statement: Not applicable.

Conflicts of Interest: The authors declare no conflict of interest.

\section{References}

1. Ugwuanyi, F.C.; Ajayi, A.; Ojo, D.A.; Adeleye, A.I.; Smith, S.I. Evaluation of efflux pump activity and biofilm formation in multidrug resistant clinical isolates of Pseudomonas aeruginosa isolated from a Federal Medical Center in Nigeria. Ann. Clin. Microbiol. Antimicrob. 2021, 20, 11. [CrossRef] [PubMed]

2. Dawan, J.; Ahn, J. Effectiveness of antibiotic combination treatments to control heteroresistant Salmonella Typhimurium. Microb. Drug Resist. 2021, 27, 441-449. [CrossRef] [PubMed]

3. Reza, A.; Sutton, J.M.; Rahman, K.M. Effectiveness of efflux pump inhibitors as biofilm disruptors and resistance breakers in Gram-negative (ESKAPEE) bacteria. Antibiotics 2019, 8, 229. [CrossRef]

4. Martins, M.; Viveiros, M.; Couto, I.; Costa, S.S.; Pacheco, T.; Fanning, S.; Pages, J.-M.; Amaral, L. Identification of efflux pumpmediated multidrug-resistant bacteria by the ethidium bromide-agar cartwheel method. In Vivo 2011, 25, 171-178. [PubMed]

5. Aybey, A.; Usta, A.; Demirkan, E. Effects of psychotropic drugs as bacterial efflux inhibitors on quorum sensing regulated behaviors. J. Microbiol. Biotechnol. Food Sci. 2014, 4, 128-131. [CrossRef]

6. Colclough, A.L.; Alav, I.; Whittle, E.E.; Pugh, H.L.; Darby, E.M.; Legood, S.W.; McNeil, H.E.; Blair, J.M. RND efflux pumps in Gram-negative bacteria; regulation, structure and role in antibiotic resistance. Future Microbiol. 2020, 15, 143-157. [CrossRef]

7. Zgurskaya, H.I.; Malloci, G.; Chandar, B.; Vargiu, A.V.; Ruggerone, P. Bacterial efflux transporters' polyspecificity-A gift and a curse? Curr. Opin. Microbiol. 2021, 61, 115-123. [CrossRef]

8. Mion, S.; Carriot, N.; Lopez, J.; Plener, L.; Ortalo-Magné, A.; Chabrière, E.; Culioli, G.; Daudé, D. Disrupting quorum sensing alters social interactions in Chromobacterium violaceum. Biofilm. Microb. 2021, 7, 40. [CrossRef]

9. Schembri, M.A.; Kjaergaard, K.; Klemm, P. Global gene expression in Escherichia coli biofilms. Mol. Microbiol. 2003, 48, 253-267. [CrossRef] 
10. Waite, R.D.; Papakonstantinopoulou, A.; Littler, E.; Curtis, M.A. Transcriptome analysis of Pseudomonas aeruginosa growth: Comparison of gene expression in planktonic cultures and developing and mature biofilms. J. Bacteriol. 2005, 187, 6571-6576. [CrossRef]

11. Rahmati, S.; Yang, S.; Davidson, A.L.; Zechiedrich, E.L. Control of the AcrAB multidrug efflux pump by quorum-sensing regulator SdiA. Mol. Microbiol. 2002, 43, 677-685. [CrossRef] [PubMed]

12. Pages, J.M.; Amaral, L. Mechanisms of drug efflux and strategies to combat them: Challenging the efflux pump of Gram-negative bacteria. Biochim. Biophys. Acta 2009, 1794, 826-833. [CrossRef]

13. Alav, I.; Sutton, J.M.; Rahman, K.M. Role of bacterial efflux pumps in biofilm formation. J. Antimicrob. Chemother. 2018, 73, 2003-2020. [CrossRef]

14. Sun, J.; Deng, Z.; Yan, A. Bacterial multidrug efflux pumps: Mechanisms, physiology and pharmacological exploitations. Biochem. Biophysic. Res. Commun. 2014, 453, 254-267. [CrossRef] [PubMed]

15. Baucheron, S.; Tyler, S.; Boyd, D.; Mulvey, M.R.; Chaslus-Dancla, E.; Cloeckaert, A. AcrAB-TolC directs efflux-mediated multidrug resistance in Salmonella enterica serovar Typhimurium DT104. Antimicrob. Agents Chemother. 2004, 48, 3729-3735. [CrossRef] [PubMed]

16. Blair, J.M.; Piddock, L.J. Structure, function and inhibition of RND efflux pumps in Gram-negative bacteria: An update. Curr. Opin. Microbiol. 2009, 12, 512-519. [CrossRef] [PubMed]

17. Yu, E.W.; Aires, J.R.; McDermott, G.; Nikaido, H. A periplasmic drug-binding site of the AcrB multidrug efflux pump: A crystallographic and site-directed mutagenesis study. J. Bacteriol. 2005, 187, 6804-6815. [CrossRef]

18. Piddock, L.J. Multidrug-resistance efflux pumps-not just for resistance. Nat. Rev. Microbiol. 2006, 4, 629-636. [CrossRef]

19. Shang, D.; Han, X.; Du, W.; Kou, Z.; Jiang, F. Trp-containing antibacterial peptides impair quorum sensing and biofilm development in multidrug-resistant Pseudomonas aeruginosa and exhibit synergistic effects with antibiotics. Front. Microbiol. 2021, 12, 611009. [CrossRef]

20. Baugh, S.; Phillips, C.R.; Ekanayaka, A.S.; Piddock, L.J.; Webber, M.A. Inhibition of multidrug efflux as a strategy to prevent biofilm formation. J. Antimicrob. Chemother. 2014, 69, 673-681. [CrossRef]

21. Sabatini, S.; Piccioni, M.; Felicetti, T.; De Marco, S.; Manfroni, G.; Pagiotti, R.; Nocchetti, M.; Cecchetti, V.; Pietrella, D. Investigation on the effect of known potent $S$. aureus NorA efflux pump inhibitors on the staphylococcal biofilm formation. RSC Adv. 2017, 7, 37007-37014. [CrossRef]

22. Van Acker, H.; Coenye, T. The role of efflux and physiological adaptation in biofilm tolerance and resistance. J. Biol. Chem. 2016, 291, 12565-12572. [CrossRef] [PubMed]

23. Siriyong, T.; Srimanote, P.; Chusri, S.; Yingyongnarongkul, B.E.; Suaisom, C.; Tipmanee, V.; Voravuthikunchai, S.P. Conessine as a novel inhibitor of multidrug efflux pump systems in Pseudomonas aeruginosa. BMC Complement. Med. Ther. 2017, 17, 405. [CrossRef] [PubMed]

24. Pagès, J.-M.; Masi, M.; Barbe, J. Inhibitors of efflux pumps in Gram-negative bacteria. Trends Mol. Med. 2005, 11, 382-389. [CrossRef] [PubMed]

25. Kurincic, M.; Klancnik, A.; Smole Mozina, S. Effects of efflux pump inhibitors on erythromycin, ciprofloxacin, and tetracycline resistance in Campylobacter spp. isolates. Microb. Drug Resist. 2012, 18, 492-501. [CrossRef]

26. Bogomolnaya, L.M.; Andrews, K.D.; Talamantes, M.; Maple, A.; Ragoza, Y.; Vazquez-Torres, A.; Andrews-Polymenis, H. The ABC-type efflux pump MacAB protects Salmonella enterica serovar Typhimurium from oxidative stress. Mbio 2013, 4, e00630-13. [CrossRef]

27. Nishino, K.; Latifi, T.; Groisman, E.A. Virulence and drug resistance roles of multidrug efflux systems of Salmonella enterica serovar Typhimurium. Mol. Microbiol. 2006, 59, 126-141. [CrossRef] [PubMed]

28. Kwon, H.I.; Kim, S.; Oh, M.H.; Na, S.H.; Kim, Y.J.; Jeon, Y.H.; Lee, J.C. Outer membrane protein A contributes to antimicrobial resistance of Acinetobacter baumannii through the OmpA-like domain. J. Antimicrob. Chemother. 2017, 72, 3012-3015. [CrossRef]

29. Nikaido, H.; Basina, M.; Nguyen, V.; Rosenberg, E.Y. Multidrug efflux pump AcrAB of Salmonella typhimurium excretes only those beta-lactam antibiotics containing lipophilic side chains. J. Bacteriol. 1998, 180, 4686-4692. [CrossRef]

30. Siala, W.; Kucharikova, S.; Braem, A.; Vleugels, J.; Tulkens, P.M.; Mingeot-Leclercq, M.P.; Van Dijck, P.; Van Bambeke, F. The antifungal caspofungin increases fluoroquinolone activity against Staphylococcus aureus biofilms by inhibiting $N$-acetylglucosamine transferase. Nat. Commun. 2016, 7, 13286. [CrossRef]

31. Soto, S.M. Role of efflux pumps in the antibiotic resistance of bacteria embedded in a biofilm. Virulence 2013, 4, 223-229. [CrossRef] [PubMed]

32. Abisado, R.G.; Benomar, S.; Klaus, J.R.; Dandekar, A.A.; Chandler, J.R. Bacterial quorum sensing and microbial community interactions. Mbio 2018, 9, e02331-17. [CrossRef] [PubMed]

33. Henderson, P.J.F.; Maher, C.; Elbourne, L.D.H.; Eijkelkamp, B.A.; Paulsen, I.T.; Hassan, K.A. Physiological functions of bacterial multidrug efflux pumps. Chem. Rev. 2021, 121, 5417-5478. [CrossRef] [PubMed]

34. Kendall, M.M.; Sperandio, V. Cell-to-cell signaling in Escherichia coli and Salmonella. EcoSal Plus 2014, 6. [CrossRef] [PubMed]

35. Nucleo, E.; Steffanoni, L.; Fugazza, G.; Migliavacca, R.; Giacobone, E.; Navarra, A.; Pagani, L.; Landini, P. Growth in glucose-based medium and exposure to subinhibitory concentrations of imipenem induce biofilm formation in a multidrug-resistant clinical isolate of Acinetobacter baumannii. BMC Microbiol. 2009, 9, 270. [CrossRef] [PubMed] 
36. Baugh, S.; Ekanayaka, A.S.; Piddock, L.J.; Webber, M.A. Loss of or inhibition of all multidrug resistance efflux pumps of Salmonella enterica serovar Typhimurium results in impaired ability to form a biofilm. J. Antimicrob. Chemother. 2012, 67, $2409-2417$. [CrossRef]

37. Danilchanka, O.; Mailaender, C.; Niederweis, M. Identification of a novel multidrug efflux pump of Mycobacterium tuberculosis. Antimicrob. Agents Chemother. 2008, 52, 2503-2511. [CrossRef]

38. Andersen, J.L.; He, G.-X.; Kakarla, P.; Ranjana, K.C.; Kumar, S.; Lakra, W.S.; Mukherjee, M.M.; Ranaweera, I.; Shrestha, U.; Tran, T.; et al. Multidrug efflux pumps from Enterobacteriaceae, Vibrio cholerae and Staphylococcus aureus bacterial food pathogens. Int. J. Environ. Res. Public Health 2015, 12, 1487-1547. [CrossRef]

39. Kvist, M.; Hancock, V.; Klemm, P. Inactivation of efflux pumps abolishes bacterial biofilm formation. Appl. Environ. Microbiol. 2008, 74, 7376-7382. [CrossRef]

40. Hansen, L.H.; Johannesen, E.; Burmølle, M.; Sørensen, A.H.; Sørensen, S.J. Plasmid-encoded multidrug efflux pump conferring resistance to olaquindox in Escherichia coli. Antimicrob. Agents Chemother. 2004, 48, 3332-3337. [CrossRef]

41. Corcoran, D.; Quinn, T.; Cotter, L.; Fanning, S. Relative contribution of target gene mutation and efflux to varying quinolone resistance in Irish Campylobacter isolates. FEMS Microbiol. Lett. 2005, 253, 39-46. [CrossRef] [PubMed]

42. Horna, G.; Lopez, M.; Guerra, H.; Saenz, Y.; Ruiz, J. Interplay between MexAB-OprM and MexEF-OprN in clinical isolates of Pseudomonas aeruginosa. Sci. Rep. 2018, 8, 16463. [CrossRef] [PubMed]

43. Sakhtah, H.; Koyama, L.; Zhang, Y.; Morales, D.K.; Fields, B.L.; Price-Whelan, A.; Hogan, D.A.; Shepard, K.; Dietrich, L.E. The Pseudomonas aeruginosa efflux pump MexGHI-OpmD transports a natural phenazine that controls gene expression and biofilm development. Proc. Natl. Acad. Sci. USA 2016, 113, E3538-E3547. [CrossRef] [PubMed]

44. Janssens, J.C.; Steenackers, H.; Robijns, S.; Gellens, E.; Levin, J.; Zhao, H.; Hermans, K.; De Coster, D.; Verhoeven, T.L.; Marchal, K.; et al. Brominated furanones inhibit biofilm formation by Salmonella enterica serovar Typhimurium. Appl. Environ. Microbiol. 2008, 74, 6639-6648. [CrossRef]

45. Burt, S.A.; Ojo-Fakunle, V.T.; Woertman, J.; Veldhuizen, E.J. The natural antimicrobial carvacrol inhibits quorum sensing in Chromobacterium violaceum and reduces bacterial biofilm formation at sub-lethal concentrations. PLoS ONE 2014, 9, e93414 [CrossRef]

46. Minagawa, S.; Inami, H.; Kato, T.; Sawada, S.; Yasuki, T.; Miyairi, S.; Horikawa, M.; Okuda, J.; Gotoh, N. RND type efflux pump system MexAB-OprM of Pseudomonas aeruginosa selects bacterial languages, 3-oxo-acyl-homoserine lactones, for cell-to-cell communication. BMC Microbiol. 2012, 12, 70. [CrossRef]

47. Pages, J.-M.; Lavigne, J.-P.; Leflon-Guibout, V.; Marcon, E.; Bert, F.; Noussair, L.; Nicolas-Chanoine, M.-H. Efflux pump, the masked side of beta-lactam resistance in Klebsiella pneumoniae clinical isolates. PLoS ONE 2009, 4, e4817. [CrossRef]

48. Navarro Risueño, F.; Miró Cardona, E.; Mirelis Otero, B. Lectura interpretada del antibiograma de enterobacterias. Enferm. Infecc. Microbiol. Clin. 2002, 20, 225-234. [CrossRef]

49. Giraud, E.; Cloeckaert, A.; Kerboeuf, D.; Chaslus-Dancla, E. Evidence for active efflux as the primary mechanism of resistance to ciprofloxacin in Salmonella enterica serovar Typhimurium. Antimicrob. Agents Chemother. 2000, 44, 1223-1228. [CrossRef]

50. Bortolotti, D.; Trapella, C.; Bragonzi, A.; Marchetti, P.; Zanirato, V.; Alogna, A.; Gentili, V.; Cervellati, C.; Valacchi, G.; Sicolo, M.; et al. Conjugation of LasR quorum-sensing inhibitors with ciprofloxacin decreases the antibiotic tolerance of $P$. aeruginosa clinical strains. J. Chem. 2019, 2019, 8143739. [CrossRef]

51. Li, X.Z.; Plesiat, P.; Nikaido, H. The challenge of efflux-mediated antibiotic resistance in Gram-negative bacteria. Clin. Microbiol. Rev. 2015, 28, 337-418. [CrossRef] [PubMed]

52. Cepas, V.; Soto, S.M. Relationship between virulence and resistance among Gram-negative bacteria. Antibiotics 2020,9 , 719. [CrossRef] [PubMed]

53. Pratt, L.A.; Kolter, R. Genetic analyses of bacterial biofilm formation. Curr. Opin. Microbiol. 1999, 2, 598-603. [CrossRef]

54. Guo, B.; Abdelraouf, K.; Ledesma, K.R.; Nikolaou, M.; Tam, V.H. Predicting bacterial fitness cost associated with drug resistance. J. Antimicrob. Chemother. 2012, 67, 928-932. [CrossRef] [PubMed]

55. Lin, W.; Zeng, J.; Wan, K.; Lv, L.; Guo, L.; Li, X.; Yu, X. Reduction of the fitness cost of antibiotic resistance caused by chromosomal mutations under poor nutrient conditions. Environ. Int. 2018, 120, 63-71. [CrossRef]

56. Ebbensgaard, A.E.; Lobner-Olesen, A.; Frimodt-Moller, J. The role of efflux pumps in the transition from low-level to clinical antibiotic resistance. Antibiotics 2020, 9, 855. [CrossRef]

57. Barbosa, C.; Trebosc, V.; Kemmer, C.; Rosenstiel, P.; Beardmore, R.; Schulenburg, H.; Jansen, G. Alternative evolutionary paths to bacterial antibiotic resistance cause distinct collateral effects. Mol. Biol. Evol. 2017, 34, 2229-2244. [CrossRef]

58. Andersson, D.I.; Hughes, D. Antibiotic resistance and its cost: Is it possible to reverse resistance? Nat. Rev. Microbiol. 2010, 8 , 260-271. [CrossRef]

59. Bester, E.; Edwards, E.A.; Wolfaardt, G.M. Planktonic cell yield is linked to biofilm development. Can. J. Microbiol. 2009, 55, 1195-1206. [CrossRef]

60. Armbruster, C.R.; Parsek, M.R. New insight into the early stages of biofilm formation. Proc. Natl. Acad. Sci. USA 2018, 115, 4317-4319. [CrossRef]

61. CLSI. Performance Standards for Antimicrobial Susceptibility Testing; Twenty-ninth Informational Supplement; CLSI: Wayne, PA, USA, 2019; Volume M100.

62. Chae, M.S.; Schraft, H. Cell viability of Listeria monocytogenes biofilms. Food Microbiol. 2001, 18, 103-112. [CrossRef] 
63. Xu, H.; Zou, Y.; Lee, H.Y.; Ahn, J. Effect of $\mathrm{NaCl}$ on the biofilm formation by foodborne pathogens. J. Food Sci. 2010, 75, M580-M585. [CrossRef]

64. Hall-Stoodley, L.; Nistico, L.; Sambanthamoorthy, K.; Dice, B.; Nguyen, D.; Mershon, W.J.; Johnson, C.; Hu, F.Z.; Stoodley, P.; Ehrlich, G.D.; et al. Characterization of biofilm matrix, degradation by DNase treatment and evidence of capsule downregulation in Streptococcus pneumoniae clinical isolates. BMC Microbiol. 2008, 8, 173. [CrossRef] [PubMed]

65. Calvio, C.; Celandroni, F.; Ghelardi, E.; Amati, G.; Salvetti, S.; Ceciliani, F.; Galizzi, A.; Senesi, S. Swarming differentiation and swimming motility in Bacillus subtilis are controlled by swrA, a newly identified dicistronic operon. J. Bacteriol. 2005, 187, 5356-5366. [CrossRef] [PubMed] 